Külgazdaság, LXIII. évf., 2019. május-június (91-110. o.)

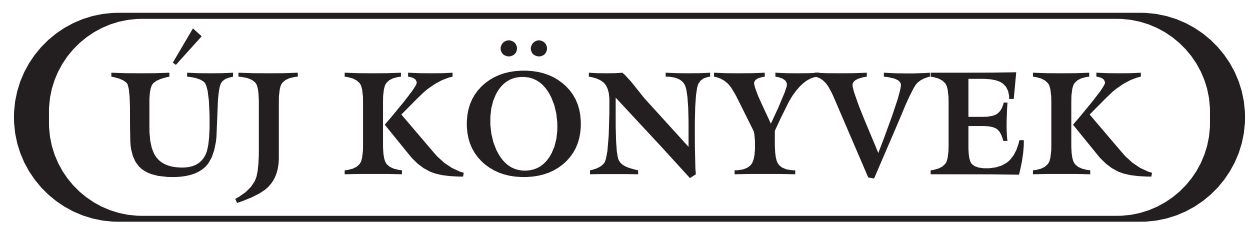

\title{
Csaba László: VÁLSÁG - GAZDASÁG - VILÁG. Adalékok Közép-Európa három évtizedes gazdaságtörténetéhez (1988-2018)
}

Éghajlat Könyvkiadó, 2018, 256 oldal

Csaba László immár több mint négy évtizede foglalkozik Közép- (és Kelet-) Európa gazdasági fejlődésével. Kiemelkedő elméleti és elmélettörténeti műveltséggel követte végig az elmúlt időszak gazdasági történéseit s elemezte négy évtized világgazdasági csomópontjait - természetesen különös figyelmet fordítva régiónkra.

Legújabb könyvének alapja a gazdaságelmélet jelentős változása (fordulata?): „A jelen elemzésben abból indulunk ki, hogy mostanra egy hasonló - az 1930-as és az 1990-es évek elejét idézö - szellemi fordulatnak lehetünk szemtanúi. Nem pusztán a hagyományos közgazdasági tételeknek széles körben és tartósan ellentmondó gazdaságpolitikára kell gondolnunk. Utóbbiban a tartósan negatív kamatok - sokszor negatív nominális kamatok - és az ezzel társuló költségvetési lazítás trenddé válása említhető. Hanem arra is, hogy szerte Európában és a világon megerősödött az állami szabályozás, az állami beavatkozás iránti igény. Nem pusztán a rendszer egészén kívül álló protesztpártok és más populista mozgalmak tüzték ezt zászlajukra. Az angol szaknyelvben „,mainstreaming”-nek elkeresztelt módon a hatalomban lévő vagy arra valós eséllyel pályázó pártok és mozgalmak, valamint az őket támogató szélesebb elemzői kör is magáévá tette ezt a felfogást." (12. oldal - kiemelés az eredetiben.) 
Könyvtárnyi tanulmány jelent meg 2018-ban arról, hogy hol tart a világgazdaság tíz évvel a II. világháború utáni korszak legsúlyosabb válsága ${ }^{1}$ után. Csaba László azonban ennél hosszabb távra tekint vissza, s régiónk három évtizedes gazdasági fejlődését elemzi. Ez az időhorizont magától értetődő: a tudományos vizsgálódás a közép- (és kelet-) európai rendszerváltástól eltelt időszakot tárgyalja. Az elemzés négy ország fejlődésének alapos feldolgozásából vonja le a közép- (és kelet-) európai gazdasági fejlődés általános tanulságait.

Németország mint Európa legjelentősebb gazdasága a tizenkilencedik század utolsó harmada óta meghatározó hatást gyakorol Közép- és Kelet-Európa gazdaságának egészére. Lengyelország a régió legnagyobb és legnépesebb, leginkább meghatározó geostratégiai pozíciójú országa. Oroszország (mint a Szovjetunió jogutódja) vizsgálata pedig elengedhetetlen a kiinduló helyzet megértéséhez, és politikai befolyása sem a régió egészére, sem egyes országaira nem elhanyagolható. Magyarország helyzetének meghatározása, fejlődésének elemzése és értékelése pedig magától értetődően kapcsolódik Közép-Európa fejlődéséhez.

Csaba László a rendszerváltás utáni helyzetet Eltérö utakon eltérö végpontokba (1988-1999) cím alatt tárgyalja, amelyet Az Európai Unió mint választóvonal címü fejezet követ. Az elhalasztott lehetőségek évtizede: 1999-2008 címü fejezete a globális válság előtti évtized történéseit elemzi. A két évtized gazdasági eredményeinek - és kudarcainak - összefoglalását tartalmazó, következő fejezet sokatmondó címe: Országtanulmányok: felzárkózás és fel nem zárkózás. A könyv második része a harmadik évezred világgazdasági korszakváltását taglalja - kiemelt figyelmet fordítva a 2008-as válság tanulságaira és az elmúlt évtized válságkezelési tapasztalataira, ezen belül vizsgálja az Európai Unió „válságát és megújulását”, az európai integráció átrendeződését a világgazdaság új korszakában. Az összefoglaló értékelést $A$ teljesitmények szóródása: okok és következmények címü fejezet tárgyalja, hogy azután Csaba László megkísérelje megválaszolni a mindnyájunkat gyötrő kérdést: Miért is maradt el az új gazdasági csoda?

Mivel 1990 a közép- és kelet-európai rendszerváltások éve, alighanem ezért tekintik meglehetősen általánosan a „rövid huszadik” és a huszonegyedik század közötti gazdaságtörténeti szakaszhatárnak. Ugyanakkor széles körben elfogadott a globalizáció kibontakozását is ehhez a szakaszhatárhoz kötni - bár ebben a fo-

${ }^{1}$ A recenzens a „2007-2009-es válság” kifejezés használatát tartja célszerünek, mivel a válság közvetlen kiváltó oka az USA-ban 2007-ben kitört jelzálogpiaci krízis volt, amelynek a mélypontját a 2009. évi súlyos recesszió jelentette. Igen elterjedt ugyanakkor a 2008-as válság kategóriájának használata, miután a pénzügyi válság a Lehman Brothers szeptember 15-én bejelentett csődjével vált nyilvánvalóvá. 
lyamatban egy év aligha meghatározható. A két értelemben is új gazdaságtörténeti korszak a régiónak a Csaba László által elemzett négy országát természetesen rendkívül eltérő kiindulóhelyzetben találta. Vegyük ezeket sorra!

Lengyelország a nyolcvanas éveket a gazdasági stagnálás és a tartós szükségállapot ellenére szellemi és politikai pezsgésben töltötte, ami - a harmadikutas megoldások elvetése és a fokozatos reformok eredménytelenségének tudatában felkészítette a lakosságot a hiperinfláció és a sokkterápia elviselésére abban a rövid időszakban, amely közvetlenül a kommunizmus bukását követte. Csaba László ezekkel a tényezőkkel - is - magyarázza, hogy az ország az átalakuló gazdaságok közül „először állt növekedési pályára”. Noha kétségtelen, hogy Lengyelország 1992-ben és 1993-ban is pozitív növekedési teljesítményt realizált, az igazi - mert fenntartható - növekedési pályára csak azt követően állt/állhatott rá, miután 1981 óta nem fizetett külső adósságait sikerült átütemeztetnie.

Németország - váratlanul gyors - újraegyesítése a korábban is Nyugat-Európa legerősebb gazdaságaként müködő NSZK-hoz hozzácsatolt egy „mezzogiornó”-t, ${ }^{2}$ amely Németország esetében az öt keleti tartományt jelenti. Az újraegyesítés formailag az NSZK gazdasági és jogi rendszerének a volt NDK-ra való kiterjesztése révén valósult meg, míg a gazdasági integrációt a valutaunió alapozta meg, amelynek során a keletnémet márka egy egységét egy nyugatnémet márkára váltották. Ez történelmileg/politikailag alighanem elkerülhetetlen volt, ugyanakkor hatalmas terhet rótt az egyesült Németország államháztartására. Becslések szerint az öt keleti tartomány integrálása és valamelyes felzárkóztatása évi mintegy 160 milliárd euróval terhelte meg a költségvetést. Ahogy Olaszországban nem volt elég másfél évszázad a Dél számottevő felzárkóztatásához, úgy ez egy generáció alatt Németországban sem valósulhatott meg: ,az intézményépítés - a legnehezebb feladat - megoldódott, mint a magánosítás és a stabilizáció is. A piacra sok új szereplő lépett be, az egykori NDK az EU részesévé vált, mezőgazdasági és területfejlesztési pénzeket kapott, lakosai az uniós képzési és vállalkozási programokhoz hozzáfértek nyomban. És mégis: a második csoda, a mindenki által várt Wirtschaftswunder ezúttal is elmaradt. Vélhetően részben épp ez magyarázza - a legtöbb megfigyelő szerint - azt a tényt, hogy

2 Mezzogiorno: Olaszország déli része, amely az ország északi részénél hagyományosan sokkal elmaradottabb. Noha 1950 és 1992 között Olaszország volt Nyugat-Európa legdinamikusabban fejlődő országa, az Észak és a Dél közötti gazdasági fejlettségbeli különbség nem csökkent számottevően. 
a keleti tartományokban volt és maradt erős a szélsőbal és a szélsőjobb is." (51. oldal - kiemelés az eredetiben.)

Oroszország nem tudta „a kört négyszögesíteni”, a kilencvenes évek kísérlete a „normális országgá válásra” kudarcot vallott. Jóllehet immár három évszázados történelmi hagyományát folytatva egyfajta piacgazdasággá vált, de egy politikailag erősen központosított, illiberális rendszerben. Csaba László pályája kezdete óta folyamatosan elemezte a Szovjetunió, illetve Oroszország fejlődését, elméleti következtetése egyértelmü: „a szovjet birodalom szétbomlása egyedi történelmi folyamat, ami kevéssé alkalmas arra, hogy a globális társadalom és gazdaság egészére nézve érvényes általánosítások alapjául szolgáljon (amit az ismert „a történelem vége” értelmezés sugall). Másfelől kétségtelenné vált az is, hogy más társadalmi és gazdasági közegben, más gazdasági teljesítmény és az elnyomó apparátus másfajta - kíméletlen - müködtetése esetén a történelmileg lemaradó rendszerek életképességét nem szabad alábecsülni." (53. oldal)

Magyarország az átalakulás éltanulója volt - elsősorban azért, mert már 1987ben elkezdődtek azok a jogi és gazdaságpolitikai változások, amelyek egy modern piacgazdaság intézményi kereteinek kialakulását megalapozhatták. A transzformációs válság persze itt sem volt elkerülhető: a GDP csaknem ötöde enyészett el, s legalább 1200000 munkahely veszett el. Magyarország - az Antall-kormány permanens válságkezelése után - a Bokros-csomagként elhíresült stabilizációs program, a tömeges privatizáció alapvetően piacalapú lebonyolítása és az euroatlanti architektúrához való csatlakozás révén 1998-ra lezártnak tekinthette a piacgazdasági átalakulást - már amennyiben az egyáltalán valaha is lezártnak tekinthető. Ugyanakkor a „magyar kapitalizmus arcélét meghatározta, hogy a nagy cégek és a nagy bankok kétharmad-háromnegyed részben külföldi tulajdonba kerültek. Ez egyfelöl megelőzte a másutt - Romániától Albánián át Lettországig - megfigyelt súlyos kezdeti visszaéléseket. Másfelől a döntések külföldre csúszása és a hatalom egyenlőtlen megoszlása a társadalom jelentős részében keltett ellenszenvet.” (60. oldal)

Az 1999-2008 közötti időszakot Csaba László az elszalasztott lehetőségek évtizedének tartja. Ez az időszak a világgazdaság egésze szempontjából nem tekinthető önálló korszaknak, a 2001-es recessziót pedig a szerző gyakorlatilag nem tárgyalja. Utóbbinak a következményei már csak azért is érdekesek a közép- és kelet-európai régióban, mert a - gazdaságtörténetileg páratlanul hosszú, 47 negyedéves fellendü- 
lés után szükségszerủen bekövetkezett - recesszió az USA-ban mindössze három negyedéven át tartott, Németországban azonban két és egynegyed évig húzódott el. Ez pedig az egész közép- és kelet-európai régiónak a növekedési lehetőségeit viszszafogta. Így az 1999-2008 közötti évtized nem nyújtott „kivételes lehetőségeket” Európának. A korszak elemzéséből levonható végső következtetés sem hathat az újdonság varázsával: „Mint annyiszor, a társadalom-lélektani elemek hatása erösebbnek bizonyult a pusztán anyagi és érdekvezérelt megfontolásoknál. Ismét nem a racionális várakozások alakították ki a gazdaságtörténetileg ma már egyértelműen látható és megítélhető végkifejletet." (123. oldal - kiemelések az eredetiben.)

Az elmúlt évtized világgazdasági eseményeinek, az egyes nemzetgazdaságok elmúlt évtizedben nyújtott gazdasági teljesítményének az értékelése a válságra adott gazdaságpolitikai válaszok, a válságkezelés elemzése révén valósítható meg. Csaba László szerint a válság ,a legfejlettebb államok - Nagy-Britannia, az Egyesült Államok, kontinentális Európa - országaiban, ott is a pénzügyi közvetítőrendszerben keletkezett, majd átterjedt más fejlett államokra a globalizáció révén. Mikor nyílttá vált, jelentős reálgazdasági hatással - a termelés és a foglalkoztatás nemzetgazdasági szinten érzékelhető, tartós visszahúzódásával, cégek tönkremenetelével, a közadósság megnövekedésével - társult.” (142. oldal)

Véleményünk szerint ez több ponton is vitatható: a pénzügyi válság egyértelmüen az USA-ban tört ki, onnan terjedt el a nemzetközi pénzügy rendszer egészében. (Ennyiben is erősen hasonlított az 1929-1933-as válsághoz.) A jelzálogpiaci válság tipikusan amerikai jelenség volt, az amerikai ingatlanfinanszírozás sajátosságaiban gyökerezett. A mérgezett eszközökről később kiderült, hogy azokat nem kizárólag az USA pénzintézetei tartják, emiatt az egész nemzetközi pénzügyi közvetítőrendszer megrendült. A reálgazdasági hatás - a súlyos recesszió - két okból is elkerülhetetlen volt. Egyrészt számos ágazat már kizárólag hitel/lízing révén értékesített, így a Lehman Brothers csődje után a járműgyártás, az építőipar, a nyomdaipar, a légi közlekedés és több más ágazat súlyos recessziója nyilvánvalóan elkerülhetetlen volt. Másrészt a súlyos pénzügyi válságok közvetlenül a reálgazdaság recessziójához vezetnek.

A fejlett országok kormányzatai ambivalensen viszonyultak a dereguláció kiszélesedéséhez és általánossá válásához, valamint a pénzügyi közvetítórendszerekben megjelent nagyszámú új, innovatív termék elterjedéséhez. Nem gondoskodtak arról, hogy pótolják az általános adócsökkentés miatt kiesett bevételeket a költségvetésben, a pénzügyi szabályozásban pedig az észszerütlen korlátozások és a szélsőséges be nem avatkozás gyakorlata egyidejüleg érvényesült. 
A válságkezelők bátran alkalmaztak merőben szokatlan eszközöket is, a jegybanki állampapír-vásárlásoktól egészen a negatív reálkamatokig. „Önmagában az, hogy a visszaesés idején átmeneti jelleggel még negatív kamatláb is kialakulhat, sem újdonságnak, sem kifogásolhatónak nem mondható. Ugyanakkor merőben újszerü, hogy a laza monetáris politika tartóssá válik, és a visszaesést követően is még éveken át fönnmarad. Ez nem szerepel sem Keynes, sem a legtöbb követőjének könyveiben.” (145. oldal) A válságkezelés első eleme a monetáris lazítás és a jegybanki kötvényvásárlás volt - ez utóbbi, mint Csaba László megjegyzi, voltaképpen a költségvetési kiadások növeléseként értelmezhető. „Az általános keretföltételek alakítása mellett a kormányzatok nem késlekedtek a nemzetgazdaság szempontjából fontosnak vélt cégek kimentésében sem, és messze nem pusztán a pénzügyi szektorban. ${ }^{3}$ (145. oldal) Két további alapvető magyarázata van annak, hogy a 2007-2009. évi pénzügyi válság nem változott az 30-as évek nagy világválságához hasonló katasztrófává. Az egyikben követhetjük Bernanke elnök gondolatmenetét. ${ }^{4}$ A lényeg az, hogy most - a hat évtizeddel korábbival ${ }^{5}$ szöges ellentétben - a központi bankok egybehangoltan léptek. ${ }^{6}$ A kamatcsökkentést néhány percen belül a többi jegybank is követte, ezzel elkerülve a pénzvilágot szétziláló versengést. Az új kommunikációs formák, a valós idejü egyeztetést lehetővé tevő világháló mellett ez új lehetőség volt, amellyel éltek. A másik nem kevésbé fontos - bár a szakirodalomban rendre mellözött - elem az automatikus stabilizátorok jelenléte volt. Utóbbi azt jelenti, hogy az állam szerepe és kiadásai alapvetően megváltoztak a harmincas évekhez képest. Az OECD-országok átlagban a GDP 40 százalékát osztják el újra, ami azt jelenti, hogy

${ }^{3}$ Csaba László joggal teszi hozzá ehhez, hogy „minden mentő intézkedés a gazdaságelmélet által elmarasztalt »erkölcsi kockázat (moral hazard) veszélyét hordozza. Hiszen a téves lépések költségeinek átháríthatósága további téves lépések megtételére csábíthat és csábított is.” (146. o.)

${ }^{4}$ Lásd: Bernanke, Ben S. [2017]: Volt merszünk cselekedni. Emlékirat egy válságról és utóéletéröl. Napvilág Kiadó.

${ }^{5}$ Csaba László nyilván az 1929-1933-as nagy válságra utal - ami nyolc évtizeddel korábban zajlott le.

${ }^{6}$ Voltaképpen a Bretton-Woods-i rendszer - amely nem mellesleg a világgazdaság történetének legnagyobb, bő negyedszázadig tartó fellendülésének alapjául szolgált, s amely máig meghatározó szerepet játszó multilaterális gazdasági-pénzügyi intézményeket teremtett - voltaképpen két nagy tanulságon alapult. Egyrészt azon, hogy az I. világháborút lezáró békeszerződések olyan káros gazdaságpolitikai döntésekhez vezettek, amelyeket jó lett volna elkerülni (t. i.: a vesztesek sem zárhatók ki a háború utáni együttmúködésből), másrészt az 1929-1933-as válság kitöréséhez és elmélyüléséhez három súlyos gazdaságpolitikai baklövés vezetett: a restrikciós hullám, a leértékelési verseny és a versengö protekcionizmus. Azaz: a válság csak átfogó együttmüködéssel kezelhetö - s ezt a nagyon erős üzenetet hordozta 2008-ban a világ hat legnagyobb jegybankjának (a Fed, az Európai Központi Bank, a Bank of England, a Bank of Canada, a Bank of Japan és a People's Bank of China) egy napon bejelentett félszázalékos kamatcsökkentése. 
a nemzetgazdasági kiadások fele nem konjunktúraérzékeny, mint néhány évtizede is volt." (145-146. oldal)

Csaba László ehhez hozzáteszi: „Nem vitatva tehát azt, hogy az önmagára hagyott piac vélhetőleg még pusztítóbb hatással múködött volna, a megvalósult, államelvü megoldások súlyos következményeit is ki kell emelnünk." (147. oldal - kiemelés az eredetiben.) A szerző kiemeli, hogy a fönntartható javuláshoz a szokásosnál tágabban értelemben kell felfogni a költségvetés feladatait. A gazdaságszerkezet változásai/változtatása, az oktatás és a munkapiac alakítása, valamint a műszaki haladás és az innováció számára kedvező társadalmi-gazdasági környezet megteremtése és fenntartása a meghatározó. Csaba László nem csekély malíciával kénytelen megállapítani, hogy ,a maga idejében ez a felfogás jelentős többségi támogatással bírt, az ellenkező gyakorlat tartósulása nyilván az elmélet képviselőit is elgondolkoztatta. Az azonban nem kétséges, hogy az elmélet - mint annyiszor - inkább követte, semmint alakitotta a gazdaságpolitikai gyakorlatot. Nem mintha nem lettek volna az újkeynesi közelítésnek jeles képviselöi a tudományban, Paul Krugmantól Joseph Stiglitzen át Olivier Blanchard-ig. Mégis, míg ők korábban egy elfogadott kisebbség képviselői voltak, napjainkra már nem kétséges, hogy a - tudományos lapokétól eltérö- gazdaságpolitikai fösodort épp ök képviselik. Szerintük nyilván nincs szükség irányváltásra, hiszen - mint láttuk - a gazdaság 2012 óta Európában és 2009 óta az Egyesült Államokban megfigyelt élénkülését egyértelműen a heterodox politikák sikerének tudják be." (148. oldal - kiemelés az eredetiben.)

A válságkezelés még tíz év elteltével sem tekinthető befejezett, lezárt folyamatnak. A következtetéseket - a kimenet bizonytalanságát hangsúlyozva - Csaba László hat, a válságkezelés lényegének tanulságait és következményeit összefoglaló pontban foglalja össze:

- az állami szabályozás kiterjesztése nem oldja meg a problémákat;

- a szabálykövető gazdaságpolitikához való visszatérés növelné a piaci szereplők bizalmát;

- szükséges az átláthatóság erősítése;

- a kormányzatnak nem akadályoznia, hanem fokoznia kell a piac tisztulását;

- elsősorban a gazdaságpolitikai gondolkodás változott: „2007 óta nem a reálgazdaságban és nem a világgazdasági eröviszonyokban ment végbe korszakváltás" (151. oldal - kiemelés az eredetiben.);

- a 2007 óta eltelt évtizedben a világgazdasági változások nem voltak kedvezőtlenek a feltörekvő és átalakult országok számára. 
Németország: egy igazi gradualista sikertörténet ${ }^{7}$ - foglalja össze Csaba László az elmúlt három évtized németországi gazdasági fejlődését, hiszen ,a német gazdaságban az európai vitákat uraló depressziónak és deflációnak nincsen nyoma". (205. oldal - kiemelés az eredetiben.) S bár Németország, pontosabban az NSZK már három évtizede is Nyugat-Európa legerősebb gazdasága volt, a siker egyáltalán nem volt kezdettől fogva nyilvánvaló, hiszen a nyolcvanas évekre kialakult strukturális problémák és a változatlan szerkezetben nehezen finanszírozható jóléti rendszerhez az újraegyesítés évi 160 (!) milliárd eurós terhe járult. A siker - az induló helyzet nehézségei ellenére - nem megmagyarázhatatlan, Csaba László a következő elemeket minősíti biztosan felsorolhatónak:

- szakszerü, kiszámítható és folytonos kormányzati politika;

- a kis- és közepes vállalatok dominanciája, amely a német gazdaságot innovatívvá és folyamatos megújulásra képessé teszi;

- a német gazdaság és társadalom transznacionalizálódása (a német gazdaság és társadalom beilleszkedése a globalizáció rendjébe) jelentős feszültségek nélkül zajlott le;

- a szociális piacgazdaság a globalizáció korában is kiállta az idő próbáját;

- Németország az európai integrációnak nemcsak legerősebb, de minden tekintetben meghatározó gazdaságává vált, anélkül hogy európai partnereiben a hegemóniára törekvés félelmét keltette volna fel;

- Németország a II. világháborút követő egész időszakban, generációról generációra öröklötten ragaszkodott az alkotmányossághoz mint társadalmi és politikai alapértékhez.

- A harmadik évezred kihívásaiban is megerősödött a társadalmi részvételhez és a szubszidiaritáshoz való ragaszkodás, az együtt döntés rendszere folyamatosan fékezi a társadalmi-gazdasági konfliktusokat, feszültségeket. (207-209. oldal)

Lengyelország helyzete ellentmondásos, mert egyrészt minden várakozással ellentétben „a történelmi átalakulási folyamat talán legnagyobb nyertese” (210. oldal

${ }^{7}$ Fiatalabb - és a gazdaságtörténet iránt kevéssé érdeklődő - olvasóknak talán érdemes elmagyarázni: a rendszerváltást követő korszak éles nemzetközi tudományos és politikai vitája zajlott arról, hogy a fokozatos/graduális fejlődés vagy a sokkterápia vezet-e az átalakulás/transzformáció hatékonyabb megvalósításához. A sokkterápia tipikus példáját Lengyelország nyújtotta, ahol a két egymást követő évben kialakult hiperinfláció magától értetődően ezt eredményezett. 
- kiemelés az eredetiben): az egy főre jutó GDP/GNI dinamikus bővülését jellemzi, hogy immár elhagyta Magyarországot, szervesen beépült az euroatlanti integrációs rendszerbe, szilárd piacgazdaságot teremtett. Ugyanakkor Lengyelországban változatlanul rendkívül nagyok a területi különbségek, az aktív korú népességnek csak mintegy a fele foglalkoztatott, az ötöde külföldön dolgozik, a bruttó állótőkeképződés erősen ingadozik, s a korábbi dinamikus növekedés évi átlagosan 2,5-3,0 százalékra csökkent. Az alacsonyabb növekedés és a rendkívül egyenlötlen elosztási viszonyok jelzik, hogy „a modell kifutó, a sikerek nem ismétlődnek önmaguktól”. (216. oldal - kiemelés az eredetiben.)

Oroszország - a kilencvenes évek reményei ellenére - a hagyományos, történelmileg determinált pályán halad: globális politikai és katonai tényező, igen gyönge gazdasággal - ahogy Csaba László fejezetcíme mondja: Kuvait atomfegyverekkel. (2016. oldal) Az export 85 százalékát változatlanul nyersanyagok, föként energiahordozók adják: 2007-2008-ban a magas kőolaj- és földgázárak 8 százalékos éves gazdasági növekedést is eredményeztek, de a normális szintjükre csökkent árak nyomán hároméves visszaesés következett, amelyet az elmúlt két évben igen mérsékelt növekedés követett. „Oroszország elmaradt szerkezeti változásai és a külső és belső elemzők által egyaránt kárhoztatott intézményi alulfejlettség, katonai vízfej és a központi bürokratikus irányítás helyreállítása okán válik kicsi és érdektelen országgá a globális gazdasági - főleg a ma már abszolút meghatározó pénzügyi - áramlások szempontjából, a világpiac legtöbb szereplője szempontjából szemlélve.” (221. oldal)

Magyarországon a 2010 óta követett gazdaságpolitika két tartós s egyben meghatározó eleme a külső és belső adósság visszaszorítása, kordában tartása. A külkereskedelmi mérleg elsődleges egyenlege és a folyó fizetési mérleg évröl évre többletet mutat. Ez igen ritka helyzet - a magyar fejlettségi szinten álló országokban éppen úgy, mint a magyar gazdaságtörténetben. S amennyire örvendetes, hogy a külső adósság csökken, annyival szerencsésebb, amikor a GDP folyamatos növekedése révén „növi ki” egy ország az adósságát, hiszen a hazai helyzet voltaképpen „a tartós tőkekiáramlás és a magánszektor igen csekély - amortizáció nélkül a GDP alig 1 százalékát kitevő - beruházási hajlandóságának tükörképe, vagyis a hosszabb távú helyben járás elöjele és egyben receptje is". (226. oldal - kiemelések az eredetiben.)

Hasonlóképpen ellentmondásosnak értékelhetjük a belső adósság alakulását. Az államháztartási hiány 2012 óta évről évre kisebb a maastrichti határértéknél, a maxi- 
málisan megengedett három százaléknál. Ez még akkor is pozitívan értékelendő, ha a magán-nyugdíjpénztári megtakarítások egyoldalú államosítása és az ideiglenesnek ígért különadók fenntartása is kellett hozzá. Ám ebben a tekintetben is akad valódi probléma. „Évről évre, sőt negyedévről negyedévre a kormányzati rögtönzés volt a jellemzö. A vizsgált évtized egészében megfigyelhettük, ahogy nemritkán még novemberben is módosították a költségvetést, és a törvényhozásnak az ehhez képest mért eltérését jelentették csupán. Ez bizony az 50-es évek óta megfigyelt költségvetési gyakorlat tovább élése, és igen keveset ad ahhoz, hogy a gazdálkodók és a befektetők számára átlátható szabályok adják meg a racionális döntések kereteit.” (227. oldal - kiemelések az eredetiben.)

A végső összefoglalást, a vizsgált négy ország elmúlt három évtizedes gazdasági fejlödésének tömör értékelését Csaba László szerényen a Köztes mérleg cím alatt foglalja össze: „Németország a világ első exporthatalmából a harmadik helyre szorult, viszont széles ipari bázisa megóvta a nagy megrázkódtatásoktól, szociális modelljét meg tudta őrizni. Lengyelország felzárkózása felgyorsult, de a mozdony kifulladt, még jóval azelőtt, hogy a célállomásra - az EU-6 átlagához - ért volna. Magyarország felzárkózása megállt, minőségi értelemben erőteljes visszaesés jelei bontakoztak ki. Végül Oroszország erőteljes külföldi katonai aktivitása, hódításai a hagyományos birodalmi logikát követik. És ennek megfelelően a társadalmi és a gazdasági modell szétzilálódása, fenntarthatatlansága került elötérbe." (230. oldal - kiemelések az eredetiben.)

A rendszerváltás azt az általános reményt keltette, hogy gazdasági értelemben is megszűnik a bipolaritás, az átalakuló gazdaságok történelmileg rövidnek mondható időn belül felzárkóznak, ezzel csatlakoznak a fejlett gazdaságok és a modern demokráciák rendszeréhez. Táplálta ezt a reményt az 1990-es évek dinamikus gazdasági növekedése, a globalizáció kibontakozása - és ezt sugallta a kor közgazdasági föiránya, a neoliberalizmus is. (Ezen a ponton a recenzens nem helyesli Csaba László kategóriahasználatát, aki „,neoklasszikus szintézisről” 'ír, mivel az a keynesiánus makroökonómia és a neoklasszikus mikroökonómia II. világháború utáni szintézisét jelenti. Így voltaképpen része/részese volt a II. világháború utáni páratlan világgazdasági fellendülésnek, míg a neoliberalizmus az 1970-es évektől elterjedt, a keynesizmussal szemben álló eszmerendszer.) A kilencvenes évek első felében általánosan elterjedt volt a nézet, mely szerint ,a szabadság és a demokrácia már megvalósult, nemsokára a prosperitás is bekövetkezik". Nos, a prosperitás nem tekinthető általánosnak és semmiképpen sem mérhető az 1950-1974 közötti (évi átlagosan 5 százalékos) növekedési dinamikához; s a társadalmak többsége egyáltalán nem 
tekinti sikertörténetnek az átalakulást, $\mathrm{s}$ a polgári demokráciából való kiábrándulás sem ritka jelenség.

Bár a rendszerváltást követő két évtizedben elért eredményeket tisztes teljesítménynek tekinthetjük, mégis jogos és érthető a kérdés: „Miért nem ismétlődött meg a gazdasági csoda még annak szülőhazájában, Németországban sem? És miért nem lendítette át a rendszerváltozással egy időben új lendületet vevő európai integráció a nehézségeken az önmagukban kicsi közép-európai országokat? Miért nem tudott élni az eredendően zárt gazdaságú Oroszország a számára hosszú ideig kedvező világgazdasági helyzettel?" (235. oldal - kiemelés az eredetiben.) Csaba László joggal emeli ki, hogy a II. világháború utáni negyedszázad sikereinek a megismétlődését várni/remélni egyszerủen illúzió, hiszen az egy történelmileg teljesen egyedi, így megismételhetetlen korszak volt. Ennek magyarázataként Csaba László kizárólag Jánossy Ferencnek a helyreállítási periódusokra vonatkozó elméletére támaszkodik. Jánossy elméletének kétségtelen relevanciája mellett ugyanakkor nyilvánvalóan komoly szerepet játszott a tartósan jó konjunktúra fenntartásában a keynesiánus keresletélénkítő gazdaságpolitika és a háború után igen gyorsan kiépült jóléti államok keresletélénkítő és -stabilizáló szerepe is. E mellett fontos hátráltató tényező az intézményi merevség - elsősorban a munkapiacé. Az európai munkaerőpiac mind az USA, mind az ázsiai konkurensek munkaerőpiacával szemben hátrányban van; ez a hátrány az európai társadalmi hagyományokban gyökerezik, ezért egy-két generációnyi idő alatt aligha változtatható meg. Az amerikai „hire and fire” (vedd fel és bocsásd el) rendszer sokkal rugalmasabb és hatékonyabb az európainál, míg az ázsiai hosszú munkaidő, kikényszerített munkafegyelem, szabályozatlan túlóra rendszere, a monotóniatürés stb. ugyancsak komoly versenyelőnyt jelent Európával szemben. (Az egyre rövidülő európai munkaidő problémáját Csaba László külön pontban tárgyalja.)

A „csoda” elmaradásának további fontos oka a beruházások elégtelen nagysága, és az a tény, hogy a régióban azok nem a leginkább innovatív középvállalati szektorba irányultak. Az európai (pontosabban: kontinentális) pénzügyi rendszer bankcentrikus, ami csökkenti a hatékonyságot és növeli a politikai kiszolgáltatottságot - a rendszer stabilitása ugyanakkor nem meglepő, hiszen „az összehasonlító gazdaságtan intézményi kategóriái szerinti politika és állam vezérelte piaci modellhez ez és csakis ez volt illeszthető". (241. oldal - kiemelések az eredetiben.) Európa relatív, az észak-amerikai és az ázsiai versenytársakéhoz viszonyított tudományos kutatási és innovációs teljesítménye romlik, az európai társadalmak nem értékelik kellőképpen a teljesítményt - amit bürokratikus korlátok is fékeznek. Ezekből a té- 
nyezőkből is következően a „gazdasági csoda elmaradását bizonyára magyarázhatja az is, hogy a vizsgált országok egy része egy lassan növekvö világgazdasági térségbe, az Európai Unióba integrálódott, Oroszország pedig onnan is kimaradva, kimondottan periferiális helyzetủ és rossz teljesítményủ országokkal alkotja az Eurázsiai Szövetséget 2012 óta”. (246. oldal - kiemelések az eredetiben.)

Csaba László szívesen jellemzi magát az ordoliberalizmus híveként, ${ }^{8}$ ami a II. világháború utáni német gazdasági csodát megalapozó szociális piacgazdaság elméleti alapjának tekinthető. Szokás ezt az elméletet a német neoliberalizmus kategóriájaként leírni - de ez felettébb pontatlan, hiszen az ordoliberalizmus a szabadpiaci mechanizmusok működése mellett nagy hangsúlyt fektet az államnak a piaci működést szabályozó jogi, technikai, társadalmi, erkölcsi és kulturális keretek stabilitására. Az ordoliberalizmus hívei szerint az állam kiemelt feladata a szabályok betartatása. Ha ugyanakkor a szabályalkotást és a szabályok betartatását, a társadalmi, szociokulturális és erkölcsi viszonyok meghatározó voltát emeljük ki, nem járunk igazán messze az angolszász institucionalizmustól. A lényeg persze nem a jeles szerző elhelyezése valamilyen közgazdasági iskolába, s az sem meghatározó, hogy ő hova helyezi magát. Annál kevésbé, mert a kötet végén maliciózusan megjegyzi: „Írásunk némileg váratlanul erősen konzervatívra sikeredett.” (249. oldal)

Csaba László nem egyszerủen az elmúlt évtizedek egyik legjelentékenyebb magyar közgazdásza, hanem olyan egyéniség, akinek senkivel össze nem téveszthető stílusa, de mindenekelőtt mély - közgazdasági, társadalomtudományi, történelmi és humán - mủveltsége és tájékozottsága teszi különösen érdekessé és értékessé ezt a művét (is). Lehet, hogy a kötet záró bekezdése kissé túl szerényre sikeredett (mint tudjuk, amúgy sem egy mủ utolsó sora foglalja össze annak tartalmát és/vagy mondanivalóját. A Hamletet például Fortinbras szavai zárják: „Menj, lőjenek sort!”). Azt joggal mondhatjuk, hogy a „történelem - nem az élet tanítómestere” (253. oldal), mert a történelemből nem minden magyarázható meg. A fejlődés - mint Csaba László is kiemeli - nem mindig „pályafüggő” (path dependence, 8. oldal), de egyegy nemzetgazdaság nem is mindig lehet „pályateremtö”. (uo.) Abból azonban, hogy a régió elmúlt három évtizedbeli fejlődését nem magyarázhatjuk meg önmagában a 100-150 évvel ezelött történtekböl, nem következik sem az, hogy a történelmi tapasztalatoktól teljes mértékben eltekinthetünk, sem az, hogy a „pályateremtés” a

${ }^{8}$ A név onnan származik, hogy a teória kifejtésére az ORDO címủ, ma is létező folyóiratban került sor. (https://www.degruyter.com/view/j/ordo) 
közgazdaság-tudomány hosszú távon bebizonyosodott alaptételei ellenére sikeres lehet. Csaba László éppen azért érezheti könyvét erősen konzervatívnak, mert a vizsgált négy ország három évtizedes gazdasági fejlődését elemezve lebilincselően érdekes, sziporkázóan szellemes és nagyon mély közgazdaságtani következtetéseket megfogalmazó könyvében, elemzésében régóta ismert alapigazságok változatlan érvényességéhez jut el. A kis és közepes országok esetében is a belső erőviszonyok a meghatározók, alapvető jelentőségủ a kormányzás minősége, a gyökeres technológiai változások (a vizsgált időszakban a 4. ipari forradalom) lehetetlenné teszik a korábbi korszakok gazdaságszervezési és -irányítási módszereinek folytatását, hosszú távon fenntartható fejlődés csak az emberi tőke minőségének folyamatos javításán alapulhat - s ebből a szempontból is meghatározó a társadalmi értékrend. És ez bizony maga a „pályafüggés”.

Csáki György

Csáki György, tanszékvezető egyetemi tanár, Szent István Egyetem Gazdaság- és Társadalomtudományi Kar. E-mail: csaki001@t-online.hu 